\title{
People with high mercury uptake from their own dental amalgam fillings
}

Lars Barregård, Gerd Sällsten, Bengt Järvholm

\begin{abstract}
Objectives-To describe people with high mercury (Hg) uptake from their amalgam fillings, and to estimate the possible fraction of the occupationally unexposed Swedish population with high excretion of urinary $\mathrm{Hg}$.

Methods-Three case reports are presented. The distribution of excretion of urinary $\mathrm{Hg}$ in the general population was examined in pooled data from several sources.

Results-The three cases excreted 23-60 $\mu \mathrm{g}$ of $\mathrm{Hg} /$ day $(25-54 \mu \mathrm{g} / \mathrm{g}$ creatinine), indicating daily uptake of $\mathrm{Hg}$ as high as $100 \mu \mathrm{g}$. Blood $\mathrm{Hg}$ was $12-23 \mu \mathrm{g} /$, which is five to 10 times the average in the general population. No other sources of exposure were found, and removal of the amalgam fillings resulted in normal Hg concentrations. Chewing gum and bruxism were the probable reasons for the increased $\mathrm{Hg}$ uptake. Extrapolations from data on urinary $\mathrm{Hg}$ in the general population indicate that the number of people with urinary excretion of $\geqslant 50 \mu \mathrm{g} / \mathrm{g}$ creatinine could in fact be larger than the number of workers with equivalent exposure from occupational sources.

Conclusion-Although the average daily Hg uptake from dental amalgam fillings is low, there is a considerable variation between people; certain people have a high mercury uptake from their amalgam fillings.
\end{abstract}

(Occup Environ Med 1995;52:124-128)

Keywords: mercury; amalgam; chewing

Dental amalgam fillings release mercury $(\mathrm{Hg})$ as elemental $\mathrm{Hg}$ vapour $\left(\mathrm{Hg}^{0}\right)$, which is readily absorbed $(80 \%)$ when inhaled. Furthermore, some mercury is dissolved in saliva or swallowed as amalgam particles, a small fraction of which is absorbed in the gastrointestinal tract. In populations with many amalgam fillings, these constitute the major source of exposure to inorganic mercury. ${ }^{1-3}$

Determinations of the rate of intraoral release of $\mathrm{Hg}^{\circ}$ have been conducted by several groups, either as spot measurements ${ }^{4-7}$ before and after standardised stimulation (chewing, tooth brushing), or as repeated measurements during 24 hour cycles. ${ }^{8}$ The daily dose of $\mathrm{Hg}$ absorbed can be estimated on the basis of assumptions as to how many hours a day the amalgam fillings are stimulated, the ratio of mouth to nose breathing, and pulmonary absorption. ${ }^{13}$ Such calculations have resulted in estimates of average daily absorbed doses of 3-17 $\mu \mathrm{g} \mathrm{Hg}(1 \mu \mathrm{g}=5 \mathrm{nmol})$ a day in populations with amalgam fillings. ${ }^{3}$ Most estimates, including the 24 hour measurements, fall below $5 \mu \mathrm{g} /$ day. $^{39}$

Inorganic $\mathrm{Hg}$ is excreted in urine and faeces, with presumably slightly higher amounts in urine after long term exposure. ${ }^{2}$ In adult Swedish populations the average differences in urinary $\mathrm{Hg}$ excretion ( $\mathrm{HgU}$ ) between people with and without amalgam fillings seem to be about $2 \mu \mathrm{g} / \mathrm{g}$ creatinine $(1 \mu \mathrm{g} / \mathrm{g}$ creatinine $=0.57 \mathrm{mmol} / \mathrm{mol}$ creatinine) or $2-3 \mu \mathrm{g} / 24 \mathrm{~h} .{ }^{810-12}$ Assuming a steady state, and that the urinary route constitutes a little more than half the total $\mathrm{Hg}$ excretion, this indicates a total absorbed dose (sum of inhalation and gastrointestinal absorption) of about $5 \mu \mathrm{g} /$ day. These figures can be compared with occupational settings, ${ }^{1}$ where the first subtle effects are seen at exposures that result in $\mathrm{HgU}$ of $30-50$ $\mu \mathrm{g} / \mathrm{g}$ creatinine. In clinical cases of $\mathrm{Hg}$ poisoning, $\mathrm{HgU}$ is generally well above those concentrations. ${ }^{13-14}$

The variation between people in $\mathrm{Hg}$ uptake from amalgam fillings is, however, poorly described. We report three cases with high absorption of $\mathrm{Hg}$ from their dental amalgam fillings.

\section{Case 1}

A 50 year old woman was referred to us in 1992 from a nephrology department owing to high blood $\mathrm{Hg}(\mathrm{HgB})$ concentration. She is a lifelong non-smoker, her alcohol consumption is low, and she has worked as a grocer's cashier. One sister has rheumatoid arthritis.

She presented at a primary health care centre in 1989 with aching and swollen hands. Signs of tenosynovitis were found, together with a high erythrocyte sedimentation rate, antinuclear antibodies, and a positive rheumatoid factor. In 1990, pain spread to most of her other joints and muscles, and she also noted Raynaud's phenomenon. C Reactive protein was high and blood haemoglobin (126 $\mathrm{g} / \mathrm{l})$ around the lower reference limit. In 1991 she was referred to a nephrology department, her glomerular filtration rate was found to be normal, and there was no proteinuria. Circulating immune complexes were 
Table 1 Background data and results from biological monitoring of $\mathrm{Hg}$ in three people with high $\mathrm{Hg}$ uptake from their amalgam fillings, and corresponding data from a control group of 20 occupationally unexposed people (six men and 14 women) from the same geographical region as the three cases (case 3 was originally included in the control group, but is excluded here)

\begin{tabular}{|c|c|c|c|c|}
\hline & Case 1 & Case 2 & Case 3 & $\begin{array}{l}\text { Control group } \\
\text { (mean (range)) }\end{array}$ \\
\hline $\begin{array}{l}\text { Year of birth } \\
\text { Amalgam surfaces (n) } \\
\text { Bruxism } \\
\text { Chewing gum } \\
\text { Fish consumption }\end{array}$ & $\begin{array}{l}1941 \\
34 \\
\text { Yes } \\
\text { Yes }\end{array}$ & $\begin{array}{l}1937 \\
40 \\
\text { Not known } \\
\text { Yes, nicotine }\end{array}$ & $\begin{array}{l}1938 \\
42 \\
\text { Probably } \\
\text { Yes, nicotine }\end{array}$ & $\begin{array}{l}1949(1934-1961) \\
37(13-69) \\
3 / 20 \\
1 / 20\end{array}$ \\
\hline $\begin{array}{l}\text { (times/week) } \\
\text { Before removal of amalgam: }\end{array}$ & 1 & 2 & 3 & $1.4(0.5-4)$ \\
\hline $\mathrm{HgB}(\mu \mathrm{g} / \mathrm{l})$ & 23 (May 1992) & $\begin{array}{l}12 \text { (October 1992) } \\
21 \text { (December 1992) }\end{array}$ & 13 (July 1993) & $2 \cdot 7(0 \cdot 2-6 \cdot 6)$ \\
\hline $\mathrm{HgU}(\mu \mathrm{g} / \mathrm{g}$ creatinine) & $\begin{array}{l}\text { 48, } 54 \text { (May 1992) } \\
50 \text { (June 1992) }\end{array}$ & $\begin{array}{l}\text { 47, 36, } 53 \text { (October 1992) } \\
37 \text { (December 1992) }\end{array}$ & 25 (July 1993) * & $2 \cdot 7(0 \cdot 8-6 \cdot 7)$ \\
\hline $\begin{array}{l}\mathrm{HgU}(\mu \mathrm{g} / 24 \mathrm{~h}) \\
\mathrm{HgF}(\mu \mathrm{g} / 24 \mathrm{~h}) \\
\text { Intraoral Hg release rate }(\mathrm{ng} / \mathrm{s})\end{array}$ & $\begin{array}{l}52 \text { (June 1992) } \\
144 \text { (June 1992) }\end{array}$ & $\begin{array}{l}60 \text { (December 1992) } \\
126,168 \text { (December 1992) }\end{array}$ & $\begin{array}{l}23 \text { (July 1993) } \\
172,184 \text { (July 1993) }\end{array}$ & $\begin{array}{l}\text { Not measured } \dagger \\
\text { Not measured }\end{array}$ \\
\hline $\begin{array}{l}\text { Baseline } \\
\text { After chewing gum }\end{array}$ & $\begin{array}{l}0.26 \text { (May 1992) } \\
0.75 \text { (May 1992) }\end{array}$ & $\begin{array}{l}0.30 \text { (December 1992) } \\
2 \cdot 3 \text { (December 1992) }\end{array}$ & $\begin{array}{l}0.49 \text { (November 1988) } \\
1 \cdot 1 \text { (November } 1988)\end{array}$ & $\begin{array}{l}0.27(0.02-0.95) \\
0.36(0.04-1.0)\end{array}$ \\
\hline $\begin{array}{l}\text { After removal of amalgam: } \\
\text { HgB }(\mu \mathrm{g} / 1) \\
\mathrm{HgU}(\mu \mathrm{g} / \mathrm{g} \text { creatinine }) \\
\mathrm{HgU}(\mu \mathrm{g} / 24 \mathrm{~h}) \\
\mathrm{HgF}(\mu \mathrm{g} / 24 \mathrm{~h})\end{array}$ & $\begin{array}{l}0 \cdot 4 \text { (August 1993) } \\
2 \cdot 9 \text { (August 1993) } \\
3 \cdot 5 \text { (August 1993) } \\
2 \cdot 3,2 \cdot 3 \text { (August 1993) }\end{array}$ & $\begin{array}{l}2 \cdot 8 \text { (January 1994) } \\
6 \cdot 0 \text { (January 1994) } \\
8 \cdot 6 \text { (January 1994) } \\
2 \cdot 5,4 \cdot 4 \text { (January 1994) }\end{array}$ & $\begin{array}{l}9 \cdot 5 \text { (January 1994)§ } \\
12 \text { (January 1994)§ } \\
12 \text { (January 1994)§ } \\
65,59 \text { (January 1994) }\end{array}$ & \\
\hline
\end{tabular}

${ }^{\star} \mathrm{Hg}-\mathrm{U}$ was $28 \mu \mathrm{g} / \mathrm{g}$ creatinine in November 1988, 4.0-22 $\mu \mathrm{g} / \mathrm{g}$ creatinine in 1989, and 3.0-9.6 $\mu \mathrm{g} / \mathrm{g}$ creatinine in 1990.

†Expected mean 3-4 $\mu \mathrm{g} / 24 \mathrm{~h}$, depending on creatinine excretion.

$\ddagger$ Expected mean $68 \mu \mathrm{g} / 24 \mathrm{~h}$, as calculated from the regression equation ${ }^{18}$, based on 10 people.

After the end of chewing, but without removal of amalgam.

Dates for determination of mercury in each case are in parentheses.

moderately increased, but there were no signs of complement factor (C3 or C4) consumption. The diagnosis was probable systemic lupus erythematosus and she was treated with prednisolone and azathioprin. At her own request, her $\mathrm{HgB}$ concentration was checked and found to be high. High concentrations of $\mathrm{HgB}$ and $\mathrm{HgU}$ were confirmed by us in 1992, and the rate of release of $\mathrm{Hg}$ after chewing was higher than normal (table 1). Faecal $\mathrm{Hg}$ (HgF) also seemed to be high, although good reference data are lacking. There was no occupational source of exposure to $\mathrm{Hg}$ and a check of her husband's urine (an indirect way of checking possible domestic $\mathrm{Hg}$ contamination) showed $\mathrm{Hg}$ excretion within normal limits. She ate fish once a week.

Her odontological history showed extensive dental treatment with amalgam fillings performed in 1975, when old fillings were replaced. In 1989, when her arthralgia had developed, a dental infection was detected and treated. Dental wear compatible with bruxism was noted, and she was given an occlusal splint. In 1991 (before her $\mathrm{HgB}$ was checked for the first time) a couple of cracked fillings had been removed. She used about five chewing gums a week (one hour each). In 1992 she had five amalgam crowns and altogether 34 amalgam surfaces. There were no signs of gingivitis.

She reported slight symptoms of nervousness, anxiety, temper changes, deteriorated memory, concentration difficulties, and tiredness, all of which had developed since the mid-1970s. A general check up and neurological examination showed normal results, and there were no abnormal psychiatric signs. An objective test for tremor ("hole tremometer" and "V tremometer") 15 showed normal results. Urinary albumin excretion was normal (3-4 mg/l).

After removal of all amalgam fillings her $\mathrm{HgU}$ and $\mathrm{HgF}$ excretion decreased, as did her HgB (table 1). She also reported a general feeling of better health and experienced less concentration difficulties than previously. Sedimentation rate, autoantibodies, and circulating immune complexes were unchanged. She is still on prednisolone and azathioprin treatment (in 1993).

\section{Case 2}

A 44 year old salesman was referred to us from his dentist in 1992, owing to high $\mathrm{HgU}$. $\mathrm{He}$ is an ex-smoker as of 1991, and his alcohol consumption is moderate.

In the late 1980 s he noted pain in his extremities and in the lateral parts of his chest. In 1990 he also had palpitations and attacks of faintness. A psychiatrist suspected depression and treated him with clomipramin. At a department of internal medicine he was found to have moderate hypertension and was treated with metoprolol. Leukocytosis of unknown origin was noted. In 1991 a myocardial infarction was diagnosed. After that, coronary arteriography showed atherosclerosis in two coronary arteries, and percutaneous coronary angioplasty was performed in 1992. His leukocytosis disappeared but the diffuse pain continued, and he had periods of febrility. He also complained of general tiredness. It was suspected that he had sequelae after a virus infection, but no definite diagnosis could be made.

His dentist had noted sudden extensive caries in 1990, which was considered to be due to his use of clomipramin (decreased salivation) at the time. Amalgam treatment was given. At the patient's request, his $\mathrm{HgU}$ concentration was checked in September 1992, and found to be high, and therefore he was referred to our department.

At the examination he still complained of pain in his arms, legs, and the lateral parts of his chest. As well as general tiredness and increased need to rest and sleep, he reported moderate restlessness and concentration 
difficulties. We confirmed high $\mathrm{HgU}$ excretion and increased $\mathrm{HgB}$ (table 1). The $\mathrm{Hg}$ release from dental amalgam fillings was high after stimulation with chewing gum. There was no occupational exposure, and no $\mathrm{Hg}$ in air could be detected in his apartment, when checked with a Jerome mercury detector, model 411 . He ate fish twice a week. He chewed about eight pieces of gum a day, most of them containing nicotine, and estimated his total chewing time to be about $10 \mathrm{~h}$ a day. $\mathrm{He}$ had 40 amalgam surfaces (including two crowns). There was no gingivitis.

General and neurological examinations showed a blood pressure of $200 / 100$, pulse rate $52 /$ minute (on metoprolol), but no tremor or other abnormal neurological findings. His albumin excretion was normal (8 $\mathrm{mg} / \mathrm{l})$, as were blood cell counts, serum electrophoresis, serum electrolytes, thyroid and liver function, blood glucose, and serum vitamin B12. After removal of all amalgam fillings, his $\mathrm{HgU}$ and $\mathrm{HgF}$ excretion decreased as did his HgB. At the end of the removal period, he reported a general improvement of health. The pain and tiredness disappeared, and only slight restlessness and concentration difficulties remain.

\section{Case 3}

This subject was re-examined in 1993, but her high $\mathrm{HgU}$ excretion was noted as early as 1988 when she was a 50 year old woman who took part in a study of ours on exposure to $\mathrm{Hg}$ from dental amalgam in the general population. Unexpectedly, high $\mathrm{HgU}$ was found, and the possible reasons for this were further investigated. ${ }^{16}$ She had been a smoker until 1987, had moderate ( $<100 \mathrm{~g}$ per week) alcohol consumption, and had a white collar job at a hospital. She had experienced some exertional dyspnoea since the 1970 s, and she took thyroxin supplement due to hypothyreosis detected in 1980, but apart from that, she considered herself to be in relatively good health. In 1991 her dyspnoea had increased and a pulmonary emphysema with lack of alpha-1-antitrypsin (homozygotic) was diagnosed. A moderate finger tremor, (both at rest and as intention tremor) was noted at the physical examination. She reported that the tremor had been present since her teenage years, and that it increased when she was tired or under stress.

Repeated determinations of $\mathrm{HgU}$ from 1988 to 1990 showed concentrations that fluctuated over the years (footnote to table 1). There was no source of exposure to $\mathrm{Hg}$ in her workplace or her home, as confirmed by measurements in air. She eats (high sea) fish three times a week. She has intermittently used chewing gum with nicotine since she stopped smoking

She has a higher number of amalgam surfaces than the Swedish average. Her dentist suspects her to be a bruxist. There are no signs of gingivitis. In 1988, the intraoral release of $\mathrm{Hg}$ was higher than normal (table 1). We concluded that the probable source of high $\mathrm{HgU}$ excretion was her own amalgam fillings. She was not interested, however, in having them removed. Her dentist gave her an occlusal splint for use during the night to avoid wear on the fillings. She used it during the second half of 1989 , but $\mathrm{HgU}$ had already decreased when she began to use it. Her use of nicotine chewing gum was also variable.

A follow up in 1993 showed that her $\mathrm{HgU}$ excretion was high again. After changing from nicotine chewing gum to wet snuff and nicotine strips, the $\mathrm{HgU}$ and $\mathrm{HgF}$ excretion seemed to decrease (table 1 ).

\section{Discussion}

These case reports show that certain people may have a high absorption of $\mathrm{Hg}$ from their dental amalgams. As this statement is based on the determination of $\mathrm{Hg}$ in biological fluids and in air, the accuracy of these determinations is crucial. The tubes and bottles used for sampling were tested, and were free from $\mathrm{Hg}$. The determinations of $\mathrm{HgB}$ and $\mathrm{HgU}$ were made with the cold vapour atomic absorption (CVAAS) technique after wet digestion at the Swedish National Institute of Occupational Health, a laboratory with extensive experience. ${ }^{17}$ Quality control with external reference samples (urine, K1 Metalle, Behring Institute, Marburg, and batch 009024, Nycomed, Oslo: whole blood, Metalle 1, Behring Institute, and batches 906 and 10010, Nycomed, Oslo) in the same analytical series as the patients' samples showed good accuracy (averages deviated $<10 \%$ from recommended values for all five types of reference samples, $n=16$ ). The analyses of $\mathrm{HgF}$ were made at another laboratory with inductive coupled plasma mass spectrometry. Quality control (BCR 186 pig kidney) indicated good accuracy $(1.98 \mu \mathrm{g} / \mathrm{g}$ (SD 0.20) $\mathrm{n}=24$ compared with the certified value of $1.97 \mu \mathrm{g} / \mathrm{g}$ ). Furthermore a comparison with another laboratory that used CVAAS showed good agreement. ${ }^{18}$ The determinations of the rate of intraoral release of $\mathrm{Hg}$ were made in our own laboratory with a design similar to that used by others. ${ }^{19}$ A Jerome mercury detector, model 411 (Jerome Instruments) was calibrated before and after the intraoral measurements, with known amounts of saturated $\mathrm{Hg}$ vapour. After three exhalations through the mouth, the subjects held their breath at end tidal volume, and immediately put a short cardboard tube in the mouth with lips placed tightly around it. The cardboard tube was tightly connected to the probe of the $\mathrm{Hg}$ detector with a rubber cork. The instrument sucks $125 \mathrm{ml}$ of air through the probe during 10 seconds. As the volume of the oral cavity is generally $<125 \mathrm{ml}$, air from the room was allowed to enter the oral cavity through a narrow plastic tube that penetrated the rubber cork. With a burette, the total volume of air that passed the $\mathrm{Hg}$ detector was kept under control. The rate of release during 12 seconds (two seconds elapsed from the end of exhalation until the start of sampling) was calculated as the average of four determi- 
Table 2 Distributions of $\mathrm{HgU}$ in 289 controls from five pooled Swedish studies (see text for references), and in 1636 subjects sampled at four local Swedish dentistry centres.

(Expected $(E)$ frequencies of high values are indicated, assuming log normal distributions with the same geometric means (SDs) as the observed (O) populations)

\begin{tabular}{|c|c|c|c|c|}
\hline & \multicolumn{2}{|c|}{$\begin{array}{l}\text { Controls from five } \\
\text { pooled studies }(n=289) \\
(\mu g / g \text { creatinine })\end{array}$} & \multicolumn{2}{|c|}{$\begin{array}{l}\text { Data from four dentistry } \\
\text { centres }(n=1636) \\
(\mu g / g \text { creatinine })\end{array}$} \\
\hline & $O$ & $E$ & $O$ & $E$ \\
\hline $\begin{array}{l}\text { Percentiles (\%): } \\
\text { Median } \\
95 \\
99 \\
99.9 \\
99.99 \\
\text { Maximum } \\
\text { Geometric mean (SD) }\end{array}$ & $\begin{array}{l}2 \cdot 1 \\
6 \cdot 2 \\
9 \cdot 0 \\
= \\
\overline{10} \cdot 3 \\
2 \cdot 0(2 \cdot 4)\end{array}$ & $\begin{array}{l}- \\
8 \cdot 1 \\
15 \\
28 \\
48 \\
-\end{array}$ & $\begin{array}{l}4 \cdot 0 \dagger \\
12 \\
20 \\
39 \\
\overline{72} \\
3 \cdot 5(2 \cdot 1)\end{array}$ & $\begin{array}{l}\overline{12} \\
19 \\
33 \\
52 \\
-\end{array}$ \\
\hline
\end{tabular}

${ }^{\star}$ Mean creatinine content $1.7 \mathrm{~g} / 1$.

tEquivalent of $2.4 \mu \mathrm{g} / \mathrm{g}$ creatinine if creatinine is $1.7 \mathrm{~g} / 1$.

nations. The procedure was then repeated after 10 minutes of chewing a standardised (soft) type of gum at a rate of 76 chews a minute with a metronome. Table 1 shows the results from this method in a control group. The baseline release of $\mathrm{Hg}$ was higher, but the increase after chewing was lower than in most other reports. ${ }^{4-8}$ The differences may be due to the type of chewing gum, and to the fact that our subjects had abstained from eating, drinking, and tooth brushing for only two hours. With the method described by Clarkson et $a l^{3}$ the estimated daily average absorbed dose in the group is $6 \mu \mathrm{g} / \mathrm{day}$, which is in agreement with previous estimates. ${ }^{13}$ The studies were approved by the ethics committee of Göteborg University.

The first and second cases had $\mathrm{HgU}$ excretions of $40-50 \mu \mathrm{g} / \mathrm{g}$ creatinine or $50-60$ $\mu \mathrm{g} / 24 \mathrm{~h}$. This is about 20 times higher than the average in Swedish control groups with amalgam fillings. If slightly more than half the absorbed dose is excreted in the urine, ${ }^{13}$ this indicates daily absorbed doses of about 100 $\mu \mathrm{g}$. The initial amounts of $\mathrm{HgF}$ were higher than in urine. Mercury in the faeces of subjects with amalgam fillings cannot, however, be used directly as an indicator of absorbed $\mathrm{Hg}$. The reason is that only a small part of the inorganic $\mathrm{Hg}$ that passes through the gastrointestinal tract is absorbed. Instead, data on what fractions of absorbed $\mathrm{Hg}$ are eliminated in urine, faeces, or by other routes, have to be collected in subjects without amalgams, or with radioisotopes. Such data from humans is scarce. ${ }^{20}$ The results from our two cases after removal of amalgam support the assumption that urinary and faecal excretion are of the same order of magnitude.

What are the possible explanations of the high $\mathrm{Hg}$ uptake in these three cases? They had similar numbers of amalgam surfaces as the controls (table 1). Their rates of release of $\mathrm{Hg}$ were higher than the average of controls after chewing, but not by a factor of 20 , and the baseline rate of release was close to the average of the control group. It has been shown in experimental studies that the use of chewing gum increases release of $\mathrm{Hg}$ from amalgams, ${ }^{7}$ and it is therefore reasonable to assume that chewing gum is one reason for the high release and uptake of $\mathrm{Hg}$. Mechanical wear on fillings due to bruxism is another probable cause. An additional possible factor is differences between people in absorption of inorganic $\mathrm{Hg}$ from the gastrointestinal tract. When seven volunteers ingested radiolabelled $\mathrm{Hg}$ nitrate, a mean (range) of $15 \%$ (9-25\%) was absorbed. ${ }^{20}$ Certain people may absorb a higher fraction.

The fact that cases 1 and 2 had better health after removal of amalgam fillings, cannot be used as evidence that their $\mathrm{Hg}$ uptake affected their health. In occupational settings, a daily dose of $\mathrm{Hg}$ leading to $\mathrm{HgU}$ excretion of about $50 \mu \mathrm{g} / \mathrm{g}$ creatinine does not generally result in clinical symptoms and signs. ${ }^{2122}$ This exposure is equivalent, however, to the one where subtle effects have been shown from the central nervous system and the kidneys in epidemiological studies. ${ }^{121-23}$ Therefore, an $\mathrm{Hg}$ uptake of this magnitude from a person's own amalgam fillings is definitely unacceptable. It corresponds to the limit for occupational exposure proposed by the World Health Organisation. ${ }^{24}$

An important issue is the frequency of high exposure to $\mathrm{Hg}$ from amalgam fillings. We have used three methods to estimate the fraction of the occupationally unexposed Swedish population that has high $\mathrm{HgU}$ excretion. Firstly, we made an inquiry to the laboratory already mentioned as to how many $\mathrm{HgU}$ analyses they had made in the last few years. The number for 1990-1992 was 3240 , and the fraction from subjects without occupational exposure was estimated to be $70 \%$, which would indicate about 2300 such samples. If no other high $\mathrm{HgU}$ concentrations were found among those samples, our first two cases detected during this period constitute 1/1150. Secondly, we pooled data ( $n=289$ ) on $\mathrm{HgU}$, corrected for creatinine, in occupationally unexposed controls from six published Swedish studies (table 2). ${ }^{12} 212325-27$ All samples were collected from first morning urine in $\mathrm{Hg}$ free polyethylene bottles, and analysed by one of three well reputed laboratories, with external reference samples for quality control in each analytical series. The distribution was positively skewed and with a log normal distribution, ${ }^{28} 29$ the expected values in the right tail were calculated. Thirdly we pooled data on $\mathrm{HgU}$ (same sampling procedure and laboratories as above, but uncorrected for creatinine) from four local dentistry authorities on subjects $(n=$ 1636) who wanted to check their $\mathrm{Hg}$ concentrations, because of anxiety about negative health effects from their amalgam fillings. The distribution was positively skewed, and estimates from a log normal distribution were made (table 2). If $\mathrm{Hg}$ from amalgam fillings does not cause symptoms, which would thereby increase the probability of a urinary sample being sent for $\mathrm{Hg}$ analysis, this group should also be representative of the general population.

Extrapolations from these three sources of data are all relatively uncertain. The distributions in the two sets of data shown in table 2 were not quite log normal, and 
especially in the case of the data corrected for creatinine, the deviation was considerable. Therefore, the extrapolations are subject to some error and cannot be used alone when the fraction of the population with high excretion is estimated. Together with our own finding of two cases in about 2300 and the observed concentrations in table 2, the extrapolations give some basis for a judgement. Our estimate from these three sources of information is that about one in 100 people in Sweden with dental amalgam fillings have $\mathrm{HgU}$ excretion of $\geqslant 10 \mu \mathrm{g} / \mathrm{g}$ creatinine. In one out of 1000 people $\mathrm{HgU}$ can be expected to be $\geqslant 25 \mu \mathrm{g} / \mathrm{g}$ creatinine. The frequency of people with $\mathrm{HgU}$ excretion of the order of $>50 \mu \mathrm{g} / \mathrm{g}$ creatinine is probably one in 2000 to one in 10000 . If this is true, 500 to 2500 people out of the 5000000 people in Sweden with amalgam fillings could have relatively high exposures to $\mathrm{Hg}$ from their fillings. This number is higher than the number of workers with equivalent exposure from occupational sources (about 50 of the chloralkali workers in Sweden). To gain further knowledge about the frequency of high exposure to $\mathrm{Hg}$ from amalgam fillings, it may be valuable to survey groups of people with amalgam fillings, who are known to be bruxists (the prevalence of intensive bruxism with signs of mechanical wear has been estimated to be $3-5 \%{ }^{30}$ ) or heavy chewers.

This work was supported by grants from the Swedish Medical Research Council and the Swedish Work Environment Fund.

1 World Health Organization. Inorganic mercury. Geneva: WHO, 1991. (Environmental Health Criteria No 118.)

2 Clarkson TW, Hursh JB, Sager PR, Syversen TLM Mercury. In: Clarkson TW, Friberg L, Nordberg GF, Mercury. In: Clarkson TW, Friberg L, Nordberg GF,
Sager PR, eds. Biological monitoring of toxic metals. New Sager PR, eds. Biological monitoring
York: Plenum Press, 1988:199-246.

3 Clarkson TW, Friberg L, Hursh JB, Nylander M. The prediction of intake of mercury vapor from amalgams. In Clarkson TW, Friberg L, Nordberg GF, Sager PR, eds Biological monitoring of toxic metals. New York: Plenum Press, 1988:247-64

4 Svare CW, Peterson LC, Reinhardt JWD, Boyer DB Frank CW, Gay DD, Cox RD. The effect of dental amalgams on mercury levels in expired air. 7 Dent Res 1981;60:1668-71.

5 Abraham JE, Svare CW, Frank CW. The effect of dental amalgam restorations on blood mercury levels. $\mathcal{f}$ Dem Res $1984 ; 63: 71-3$.

6 Patterson JE, Weissberg BG, Dennison PJ. Mercury in human breath from dental amalgams. Bull Environ Contam Toxicol 1985;34:459-68.

7 Vimy MJ, Lorscheider FL. Serial measurements of intraoral air mercury: estimation of daily dose from dental amalgam. F Dent Res 1985;64:1072-5.

8 Berglund A. Estimation by a 24 -hour study of the daily dose of intra-oral mercury vapour inhaled after release from dental amalgam. $\mathcal{F}$ Dent Res 1990;69:1646-51.

9 US Public Health Service. Department of health and human services. Dental amalgam: a scientific review and recommended Public Health Service strategy for research, education, and regulation. Washington: US DHHS, 1993.

10 Molin M, Bergman B, Marklund SL, Schütz A, Skerfving S. Mercury, selenium, and glutathionen peroxidase before and after amalgam removal in man. Acta Odontol Scand 1990;48:189-202.

11 Åkesson I, Schütz A, Attewell R, Skerfving S, Glanz PO Mercury and selenium status in dental personnelimpact of amalgam work and own fillings. Arch Environ Health 1991;46:102-9.

12 Langworth S, Elinder C-G, Göthe C-J, Vesterberg O Biological monitoring of environmental and occupational exposure to mercury. Int Arch Occup Environ Health 1991;63:161-7.

13 Bidstrup PL, Bonell JA, Harvey DG, Locket S. Chronic mercury poisoning in men repairing direct-current meters. Lancet 1951 ;ii:856-61.

14 Smith RG, Vorwald AJ, Patil LS, Mooney TF. Effects of exposure to mercury in the manufacture of chlorine. $A m$ Ind Hyg Assoc 7 1970;31:687-700.

15 Roels H, Lauwerys R, Buchet JP, Bernard A, Oversteyn $M$, Gaussin J. Comparison of renal function and psychomotor performance in workers exposed to elemental mercury. Int Arch Occup Environ Health 1982; 50:77-93.

16 Sällsten G, Barregård L, Österberg T. Tandgnissling hos amalgambärare-en orsak till hög kvicksilverutsöndring? Läkartidningen 1991;88:232-3. (In Swedish.)

17 Vesterberg $O$. Automated method for quantitation of mercury in blood, plasma and urine. F Biochem Biophys Methods 1991;23:227-35.

18 Skare I, Engqvist A. Human exposure to mercury and silver released from dental amalgam restorations. Arch Environ Health 1994;49:(in press).

19 Berglund A, Pohl L, Olsson S, Bergman M Determination of the rate of release of intraoral mercury vapor from amalgam. 7 Dent Res 1988;67:1235 42.

20 Rahola T, Hattula T, Korolainen A, Miettinen JK. Elimination of free and protein-bound ionic mercury $\left({ }^{* *} \mathrm{Hg}^{2+}\right)$ in man. Ann Clin Res 1973;5:214-9.

21 Roels H, Gennart JP, Lauwerys R, Buchet JP, Malchaire J, Bernard A. Surveillance of workers exposed to mercury vapour: validation of a previously proposed biological threshold limit value for mercury concentration in urine Am F Ind Med 1985;7:45-71.

22 Langworth S, Almkvist O, Söderman E, Wikström B-O Effects of occupational exposure to mercury vapour on the central nervous system. Br f Ind Med 1992 49:545-55.

23 Barregård L, Hultberg B, Schütz A, Sällsten G. Enzymuria in workers exposed to inorganic mercury. Int Arch Occup Environ Health 1988;61:65-9.

24 World Health Organization. Recommended health-based limits in occupational exposure to heavy metals. Report of limits in occupational exposure to heavy metals. Report of a WHO Study Group
Report Series 647 .

25 Nilsson B, Nilsson B. Mercury in dental practise. II Urinary mercury excretion in dental personnel. Swed Dent f 1986;10:221-32.

26 Molin M, Schütz A, Skerfving S, Sällsten G. Mobilized mercury in subjects with varying exposure to elemental mercury vapour Int Arch Occup Environ Health 1991;63:187-92.

27 Langworth S Elinder C-G, Sundqvist K-G. Minor effects of low level exposure to inorganic mercury on the human immune system. Scand 7 Work Environ Health 1993. 19:405-13.

28 Koch AL. The logarithm in biology. II. Distributions simulating the log-normal. $\mathcal{F}$ Theor Biol 1969;23:251-68.

29 Rappaport SM. Assessment of long-term exposures to toxic substances in air [review]. Ann Occup Hyg 1991 35:61-121

30 Ekfeldt A. Incisal and occlusal tooth wear and wear of some prosthodontic materials. An epidemiological and clinical study. Swed Dent F 1989;65(suppl). 